\title{
Reflexões acerca do Princípio do Juiz Natural
}

\author{
Michele Costa da Pilveina
}

Mestranda em Direito Civil pela Universidade Federal Rio Grande do Sul.

\section{Introdução}

Garantia da dignidade da pessoa A humana por meio da justiça, e, esta mediante um processo legal, no dizer de COUTURE, ${ }^{1}$ não é objeto de discussão. A discussão, segundo o autor, começa quando trata-se de saber o que realmente significa um processo legal e seus desdobramentos, dentre eles, a garantia do juiz natural.

1. Introdução

2. Evolução Histórica

3. O Significado do Princípio

4. O Juiz Natural nas Constituições Brasileiras

5. O Alcance do Princípio

6. Conclusão

7. Bibliografia

Assegurado pela Constituição Federal, o acesso à justiça de todos os membros da comunidade, indistintamente, coloca-se em estreita relação com essa garantia, inerente ao devido processo legal, a do juiz natural.

A importância da discussão acerca do princípio do juiz natural reside no fato de que ele respeita não somente ao Direito Constitucional, como também ao Direito Processual. Desde o fim da Segunda Guer-

1. COUTURE, Eduardo J. La "Garanzia Costituzionale del "Dovuto Processo Legale". In Rivista di Diritto Processuale, 2,1954, p. 81. 
ra Mundial, de acordo com SCHWAB, ${ }^{2}$ as normas de Direito Constitucional têm alcançado sempre um significado maior, no que concerne à jurisprudência. Na verdade, tem-se falado de uma constitucionalização do processo e também de um procedimento judicial como Direito Constitucional aplicado. As normas com este caráter têm sido chamadas, em seu conjunto, de Direito Processual Constitucional, e a ele pertence, certamente, o princípio do juiz natural.

O princípio do juiz natural apresenta, para a maioria dos autores, ${ }^{3}$ um duplo significado: primeiramente consagra-se como sendo a norma de que só é juiz o órgão investido de jurisdição, - afastando-se, julgar, impondo-se sanções penais sem processo prévio, através de leis votadas pelo parlamento, muito em voga no antigo Direito Inglês, por exemplo. No segundo significado, impede-se a criação de tribunais de exceção e ad hoc para o julgamento de causas penais ou civis. ${ }^{4}$

\section{Evolução histórica}

Para MARQUES, ${ }^{5}$ a origem da idéia na regra social do direito medieval de que desse modo, a possibilidade de o legislador informadora do princípio do juiz natural está

ninguém podia ser julgado a não ser por seus pares. Entretanto, a consagração do princípio deu-se em momento histórico bastante posterior.

É tradicional a postura que faz remontar à Carta Magna de 1215 o estabelecimento do princípio do juiz natural. ${ }^{6} \mathrm{O}$ art. 39 do referido diploma dispunha que "nenhum homem livre será preso ou detido em prisão ou privado de suas terras, ou posto fora da lei ou banido ou de qualquer maneira molestado; e não procederemos contra ele, nem o faremos vir a menos que por julgamento legítimo de seus pares e pela lei da terra", bem como, sob outro aspecto, afirmava o art. 20 da mesma Carta, que "nenhuma multa será lançada senão pelo juramento de homens honestos da vizinhança".

Contudo, adverte a mesma autora que, para a correta compreensão da garantia contida na Magna Carta, é preciso levar-se em consideração o sistema de administração da justiça na Inglaterra àque la época.

Prevalecia o sistema jurisdicional feudal, com a distribuição da justiça pelos proprietários de terras. A função jurisdicional estatal era incipiente, em que surgiam, aos poucos, os chamados juízes itinerantes, de-

2. SCHWAB, Karl Heinz. "Divisão de Funçōes e o Juiz Natural". Trad. de Nelson Nery Júnior. In Revista de Processo, 48, 1987, p. 124.

3. Alguns autores, dentre eles FERRAJOLI, Luigi. Derecuo y Razón (Teoria del Garantismo Penal). Madrid: Trotta, 1995, pp. 589/ 591, admitem um significado tripartido, significando: a necessidade da proibição da constituição do juiz post factum; a inderrogabilidade e indisponibilidade das competências; e a proibição de juízos extraordinários e especiais.

4. Cf. PENTEADO, Jaques de Camargo. "O Princípio do Promotor Natural". In RT619, 1987, p. 408.

5. MARQUES, José Frederico. "Juiz Natural". In Enciclopédia Saraiva de Direito. vol. 46, p. 446, apud BLUNTSCHILI, M. Le droit public général, 1881, p. 205

6. Cf. GRINOVER, Ada Pellegrini. O Princípio do Juiz Natural e a sua dupla garantia, O processo em sua unidade - II. Rio de Janeiro: Forense Universitária, 1984, p. 4.

Revista da Faculdade de Direito da UFRGS, v. 18, 2000 sempenhando função jurisdicional concorrentemente com as Cortes Feudais, mas que não consubstanciava-se em fenômeno de tal envergadura que justificasse a garantia da Magna Carta como o sendo contra juízes extraordinários.

$\mathrm{Na}$ verdade, de acordo com GRINOVER, ${ }^{7}$ é lícito concluir que os dispositivos dos artigos 20 e 39 da Magna Carta dirigiam-se à justiça feudal, e não à proibição de juízes extraordinários. O que a Carta assegurava aos submetidos às Cortes Feudais era o iudicium parium suorum, donde conclui a autora que a problemática do juiz natural, como hoje a entendemos, é sucessiva à época da Magna Carta. ${ }^{8}$

$\mathrm{Na}$ verdade, a naturalidade como proibição de juízes extraordinários deriva diretamente da Petition of Rights, de $1627 \mathrm{e}$ do Bill of Rights, de $1688 .{ }^{9} \mathrm{O}$ texto da Petição de Direitos, dispunha: (...) "III - E considerando igualmente que, pelo estatuto chamado A Grande Carta das Liberdades da Inglaterra, é declarado e ordenado que nenhum homem livre seja detido ou preso, ou espoliado de suas terras e liberdades, ou de seus livres costumes, ou banido e exilado, ou de qualquer maneira exilado, ou de qualquer maneira destruído, senão pelo legítimo julgamento de seus pares, ou pela lei da terra".
À época, sabe-se que existiam certas pessoas nomeadas como comissários, e que detinham poder e autoridade para procederem conforme a justiça da lei marcial. $\mathrm{Na}$ petição, então, era pedido que nenhum homem livre fosse julgado por tais comissões, que eram contrárias às leis e costumes do reino.

O Bill of Rights de 1868, então, dispôs no art. 3ำ que "a comissão que instituiu a ex-corte dos comissários e cortes da mesma natureza, é ilegal e nociva". Assim, na Petition of Rights e no Bill of Rights o princípio do juiz natural realmente toma os contornos atuais, de proibição de juízes ex post facto e de juízes extraordinários.

Posteriormente, então, em virtude de sua suma importância para o cidadão, o princípio do juiz natural encontrou abrigo em muitos textos constitucionais e internacionais modernos.

$\mathrm{Na}$ Espanha, a expressão juiz natural é substituída por juiz competente, tal qual se acha explicitada no artigo $16 \mathrm{da}$ Constituição de 1876 e no artigo 28 da Constituição Republicana de $1931{ }^{10}{ }^{10}$ garantindo a todos o direito a um juiz ordinário predeterminado pela lei. ${ }^{11}$

$\mathrm{Na}$ Alemanha utiliza-se a expressão juiz legal, em vez de juiz natural. A Cons-

7. GRINOVER, Ada Pellegrini. O Princípio do Juiz Natural e a sua dupla garantia, O processo em sua unidade - II. Rio de Janeiro: Forense Universitária, 1984, p. 5

8. No mesmo sentido, FERRAJOLI, Luigi. Derecuo y Razón (Teoria del Garantismo Penal). Madrid: Trotta, 1995, p. 590, ao afirmar que "La garantía del juez natural, (...) es, como la de independencia, una adquisición moderna. Ha sido infructuoso el intento de situar su origen en la Magna Charta (...)".

9. Cf. GRINOVER, Ada Pellegrini. O Princípio do Juiz Natural e a sua dupla garantia, O processo em sua unidade - II. Rio de Janeiro: Forense Universitária, 1984, p. 5 .

10. Cf. ALBUQUERQUE, Valéria Medeiros de. "Juiz Natural". In Revista Jurídica Consulex, ne 6, 1997, p. 36

11. Cf. GOMES, Luiz Flávio. "Apontamentos sobre o Princípio do Juiz Natural". In RT 703, 1994, p. 418. 
tituição de Weimar no seu artigo 105 preconizava a vedação de criarem-se tribunais de exceção, bem como ninguém poderia se subtraído de seu juiz legal. ${ }^{12} \mathrm{Na}$ Lei Funda mental de Bonn, em seu artigo 101, está consignado que não pode ser criada juris dição de exceção. Ninguém deve ser sub. traído de seu juiz legal. ${ }^{13}$

No direito italiano, em sua primeira versão, ficou estabelecido que "nessuno pù essere distolto daí suoi giudice naturali. Non potrano perciò essere creati tribunali comissioni straordinarie" (art. 71 do estatuto albertino) ${ }^{14}$ Hoje, a garantia encontra-se no art. 102 da Constituição Italiana de 1948, ${ }^{15}$ com a seguinte redação: (...). Non possono essere instituiti giuidice straordinari o giuidici speciali. Possono soltanto instituirsi presso gli organi giudiziari ordinari sezioni specializzate per determinate materie, anche com la partecipazione di cittadini idonei estrane alla magistratura.(...)

Também a Declaração Universal dos Direitos do Homem proclamada em 1949 pela Assembléia Geral da Organização das Nações Unidas veio a abrigar em seu artigo a garantia do juiz natural, afirmando que toda pessoa tem direito, em condições de plena igualdade, de ser ouvida publicamente

e com justiça por um tribunal independente e imparcial, para a determinação de seus direitos e obrigações ou para o exame de qualquer acusação contra ela em matéria penal, ${ }^{16}$ de acordo com MARQUES. ${ }^{17}$

A Convenção Americana sobre Direitos Humanos (Pacto de São José da Costa Rica, de 1969) estabelece em seu artigo $8^{\mathrm{o}}, \mathrm{n}^{\mathrm{O}} 1$ que "toda pessoa tem direito a ser ouvida, com as devidas garantias e dentro de um prazo razoável, por um juiz ou tribunal competente, independente e imparcial, estabelecido anteriormente por lei, na apuração de qualquer acusação penal formula da contra ela, ou para que se determinem seus direitos ou obrigações de natureza civil, trabalhista, fiscal ou de qualquer outra natureza". ${ }^{18}$

A garantia de que não haverá juízo ou tribunal de exceção está também pre sente nas Constituições da Argentina, em seu art. 18; do Chile, em seu art. 19 (3ㅇ) do Japão em seu art. 76; e de Portugal em seu art. $212(4) .^{19}$

\section{O significado do princípio}

A Constituição Brasileira de 1988 não menciona a expressão "juiz natural" em

12. Cf. ALBUQUERQUE, Valéria Medeiros de. "Juiz Natural". In Revista Juridica Consulex, $n^{2} 6$, 1997, p. 36

13. CF. GOMES, Luiz Flávio. "Apontamentos sobre o Princípio do Juiz Natural". In RT 703, 1994, p. 418.

14. Cf. GOMES, Luiz Flávio. "Apontamentos sobre o Princípio do Juiz Natural". In RT 703, 1994, p. 418.

Cf. BASTOS, Celso Ribeiro e MARTINS, Ives Gandra. Comentários à Constituiçãao do Brasil. São Paulo: Saraiva, 1989. $2^{2}$ vol. (arts. $5^{\circ}$ a 17 ). determination of any criminal charge against him".

17. Cf. GOMES, Luiz Flávio. "Apontamentos sobre o Princípio do Juiz Natural". In RT703, 1994, p. 418.

18. De acordo com GOMES, Luiz Flávio. "Apontamentos sobre o Princípio do Juiz Natural". In RT 703, 1994, p. 419

19. Cf. BASTOS, Celso Ribeiro e MARTINS, Ives Gandra. Comentários à Constituição do Brasil. São Paulo: Saraiva, 1989. $2^{2}$ vol. (arts. $5^{2}$ a 17$)$.
16. Leia-se, no original, "everyone is entitled in full equity to a fair and public hearing by na independent and impartial tribunal, in

Revista da Faculdade de Direito da UFRGS, v. 18, 2000 um determinado artigo. $\mathrm{Na}$ verdade, dada a relevância do princípio para o cidadão, ele consagra-se como garantia fundamental em mais de um dispositivo constitucional. Pode-se assim dizer que há vários dispositivos que, de maneira mais ou menos implícita, encerram a idéia e o espírito do princípio do juiz natural. São eles:

- o art. 5, XXXVII: "não haverá juízo ou tribunal de exceção";

- o art. 5, XXXV: "a lei não excluirá da apreciação do Poder Judiciário lesão ou ameaça a direito";

- o art. 50, LIII: "ninguém será processado nem sentenciado senão pela autoridade competente";

- o art. 5-, XL: "a lei penal não retroagirá, salvo para beneficiar o réu”.

Para a grande maioria dos doutrinadores ${ }^{20}$ o significado do princípio do juiz natural é o de uma dúplice garantia a proibição de juízo ou tribunal de exceção e julgamento por autoridade competente.

É o que se depreende do entendimento de GRINOVER, ${ }^{21}$ ao estabelecer as duas garantias do juiz natural, consistentes, a primeira, na proibição de juízos extraordinários, ex post facto, e, a segunda, a não detração ao juiz constitucionalmente competente.
Já para outros, ${ }^{22}$ a garantia do juiz natural deve ser entendida de forma tríplice. É o que se infere do ensinamento de FERRAJOLI, ${ }^{23}$ ao afirmar que a garantia significa, precisamente, três coisas distintas ainda que relacionadas entre si: a necessidade de que o juiz seja pré-constituído pela lei e não constituído post factum; a inderrogabilidade e a indisponibilidade das competências, e a proibição de juízos extraordinários e especiais.

No primeiro sentido, o princípio designa o direito do cidadão a um processo não pré-julgado por uma eleição de juiz posterior ao delito e por isso ordenada à obtenção de um determinado resultado. No segundo sentido, designa a reserva absoluta de lei e a inalterabilidade discricional das competências judiciais. No terceiro sentido, constitui-se em um princípio de organização que postula a unidade da jurisdição e seu monopólio nas mãos de uma única ordem.

De acordo com BASTOS e MARTINS, ${ }^{24}$ são diversos os princípios que presidem ao juízo natural. Para isso, aludem os mesmos autores às concepções de JOSÉ CELSO DE MELO FILHO, para o qual seriam os princípios da igualdade e o da legalidade, enquanto que JOSÉ AFONSO
20. Entre eles, os aqui citados MARQUES, José Frederico. "Juiz Natural". In Enciclopédia Saraiva de Direito. vol. 46, pp. 444/450 e GRINOVER, Ada Pellegrini. O Princípio do Juiz Natural e a sua dupla garantia, O processo em sua unidade - II. Rio de Janeiro: Forense Universitária, 1984, pp. $3 / 40$.

21. GRINOVER, Ada Pellegrini. O Princípio do Juiz Natural e a sua dupla garantia, O processo em sua unidade - II. Rio de Janeiro: Forense Universitária, 1984, p. 22.

22. Entre eles o aqui citado FERRAJOLI, Luigi. Derecuo y Razón (Teoria del Garantismo Penal). Madrid: Trotta, 1995, pp. 589/591.

23. Ob. Cit., p. 590. (Traduzimos e os grifos são nossos).

24. BASTOS, Celso Ribeiro e MARTINS, Ives Gandra. Comentários à Constituição do Brasil. Sắo Paulo: Saraiva, 1989. $2^{\circ}$ vol. (arts. $5^{\circ}$ a 17), p. 205. 
DA SILVA ${ }^{25}$ deposita mais importância no princípio da igualdade jurisdicional.

Para GOMES, ${ }^{26}$ ao princípio do juiz natural quatro outros princípios estão conectados: o da igualdade, o da imparcialidade, o da anterioridade e o da legalidade. $O$ juiz deve ser previamente estabelecido pela lei (autoridade competente), exatamente porque conta com as características da generalidade e permanência (intangibilidade), para estar em condições de fazer observar o princípio da igualdade de todos perante a lei, de modo imparcial.

$O$ princípio da anterioridade da lei, continua o autor, intimamente conectado com o próprio princípio da legalidade não significa outra coisa senão: a) que a lei criou o órgão jurisdicional; b) que a lei o investiu de jurisdição; c) que a lei lhe atribuiu competência; d) que tudo isso ocorreu antes do fato que ensejará o nascimento da causa judicial.

O princípio da legalidade é, sem dúvida, de suma importância para a compreensão do princípio do juiz natural. CALAMANDREI ${ }^{27}$ afirma que a garantia do juiz natural é inseparável do sistema da

legalidade. "Os princípios de 'l'astrattezza delle legge' que asseguram ao cidadão a certeza do direito e a possibilidade de conhecer em qualquer momento os limites da própria liberdade, não teriam praticamente qualquer sentido se não fossem acompanhados 'da questa parallela astrattezza dell'ordinamento giudiziario', que impede a escolha dos juízes seja feita ad personan, de forma a lhes anular antecipadamente a independência e a imparcialidade". ${ }^{28}$

De acordo com BASTOS, ${ }^{29}$ o juiz natural não o é só aquele da sentença de primeira instância, mas no princípio devem estar incluídos todos aqueles chamados a intervir em um determinado feito. ${ }^{30}$

CANOTILHO ${ }^{31}$ deu um tratamento bastante analítico ao tema, apontando as diversas dimensões fundamentais do que chama de juiz legal: a) a exigência de determinabilidade (prévia individualização através de leis gerais); b) garantia de uma justiça material (neutralidade e independência do juiz); c) princípio da fixação de competência (aplicação das regras decisivas para determinação do juiz da causa); d) a observância das determinações do proce-

25. Vide SILVA, José Afonso da. Curso de Direito Constitucional Positivo. São Paulo: RT.

26. GOMES, Luiz Flávio. "Apontamentos sobre o Princípio do Juiz Natural". In RT703, 1994, p. 420.

27. Citado por MARQUES, José Frederico. "Juiz Natural". In Enciclopédia Saraiva de Direito. vol. 46, p. 446.

28. Idem.

29. BASTOS, Celso Ribeiro e MARTINS, Ives Gandra. Comentários à Constituição do Brasil. São Paulo: Saraiva, 1989. $2^{8}$ vol. (arts. 59 a 17), p. 205.

30. No mesmo sentido, SCHWAB, Karl Heinz. "Divisăo de Funçōes e o Juiz Natural". Trad. de Nelson Nery Júnior. In Revista de Processo, 48, 1987, p. 125, ao afirmar que "o principio do juiz natural exige não só uma disciplina legal da via judicial, da competência funcional, material e territorial do Tribunal, mas também uma regra sobre qual órgão judicante (Câmara, Turma, Senado) e qual juiz em cada um desses órgãos individualmente considerados, devem exercer a sua atividade".

31. Citado por BASTOS, Celso Ribeiro e MARTINS, Ives Gandra. Comentários à Constituição do Brasil. São Paulo: Saraiva, 1989. $2^{\varrho}$ vol. (arts. $5^{2}$ a 17), p. 20 dimento referentes à divisão funcional interna (distribuição de processos).$^{32}$

\section{O juiz natural nas \\ Constituições Brasileiras}

Desde a Constituição Política do Império do Brasil, de 1824, já encontravamse indícios do que hoje resta consagrado no art. 5ํ, XXXVII da Constituição Federal de 1988 como proibição de juízo ou tribunal de exceção, com a seguinte redação: art. 179 , inc. 17 - "À exceção das causas que por sua natureza pertencem a juízos particulares, na conformidade das leis, não haverá foro privilegiado, nem comissões especiais, nas causas cíveis ou crimes".

A Constituição de 1891 , em seu art. $72, \S 23$, dispunha que: "À exceção das causas que, por sua natureza, pertencem a juízos especiais, não haverá foro privilegiado, nem tribunais de exceção; admitem-se, porém, juízos especiais em razão da natureza das causas".

A Carta Constitucional de 1937, em seus arts. 122 e 17, dispunha que "Os crimes que atentarem contra a existência, a segurança e a integridade do Estado, a guarda e o emprego da economia popular serão submetidos a processo e julgamento peran te Tribunal Especial, na forma que a lei instituir", o que, de certa forma pode ser considerado um retrocesso em relação à Constituição anterior.

A Constituição de 1946 em seu art. 141, § 26 dispunha que "Não haverá foro

32. Ainda sobre o tema do juiz natural e competência em tribunal, vide TUCCl, Rogério Lauria. "Juiz Natural e Competência em Tribunal". In RT 765, 1999, pp. 97/107. privilegiado nem juízes e tribunais de exceção", enquanto que a Carta de 1967 em seu art. 150, $\$ 15$ e Emenda Constitucional no 1 de 1969 , art. $153, \S 15$, dispunham que "A lei assegurará aos acusados ampla defesa, com os recursos a ela inerentes" e ainda mantinha a disposição de que não haveria foro privilegiado nem tribunais de exceção.

Com relação à garantia da autoridade competente para processar e julgar, outro importante aspecto do princípio do juiz natural, hoje consagrada pelo art. 5º, LIII, esteve presente também na Constituição seu art. 149 , inc. 11 , com a seguinte redação: "Ninguém será sentenciado senão pela autoridade competente, por virtude de lei anterior e na forma por ela prescrita".

A Constituição de 1891, em seu art. $72, \S 15$, dispunha em termos bastante semelhantes: "Ninguém será sentenciado, senão pela autoridade competente, em virtude de lei anterior ao fato, e na forma por ela estabelecida".

Já a Carta de 1934 trouxe inovação ao dispor que "Ninguém será processado, nem sentenciado, senão pela autoridade competente, em virtude de lei anterior ao fato, e na forma por ela prescrita". Aparece aqui, pela primeira vez, o que tornar-se-ia, posteriormente, a idéia do promotor natural, na medida em que ao dispositivo anterior foi acrescentada a expressão "processado".

Já a Constituição de 1937, em seu art. 122, inc. 13 , somente garantia, generi-

Revista da Faculdade de Direito da UFRGS, v. 18, 2000 Política do Império do Brasil de 1824, em 
camente, a irretroatividade da lei mais gravosa, ao dispor que: "As penas estabelecidas ou agravadas na lei nova não se aplicam aos fatos anteriores".

A Constituição de 1946 tentou juntar as duas idéias (autoridade competente e irretroatividade), dispondo, em seu art. 141, § 27: "Ninguém será processado nem sentenciado senão pela autoridade competente e na forma da lei anterior". Todavia nada menciona sobre quem deve ser a autoridade competente a processar.

A Constituição de 1967 bem como a Emenda Constitucional no 1 de 1969 foram completamente omissas a respeito de ambas as garantias.

A Constituição Federal de 1988, en tão, consagrou a idéia do juiz natural, basicamente, em quatro dispositivos: art. 50 XXXVII, dispondo que: "não haverá juízo ou tribunal de exceção"; art. 5으, LIII: "nin guém será processado nem sentenciado senão pela autoridade competente" (garantia do juiz competente e do promotor natural) o art. 5, XXXV: "a lei não excluirá da apre ciação do Poder Judiciário lesão ou ameaça a direito" (garantia do acesso à justiça); e através do dispositivo do art. 5ㅇ, XL: "a lei penal não retroagirá, salvo para beneficiar o réu" (irretroatividade da lei).

\section{O alcance do princípio}

Estabelecido, pois, o significado do princípio do juiz natural, cabe analisar sua dimensão dentro do ordenamento jurídico brasileiro, para assim determinar-se seu alcance, sua incidência, e as eventuais infringências a ele existentes nos tempos atuais.

Em primeiro lugar, é preciso esclarecer que o "tribunal de exceção", vedado pela Constituição Federal de 1988, não se confunde com "foro privilegiado", porque este último é direito subjetivo de que alguém é titular, como o do Presidente da República, dos Ministros de Estado, dos Ministros do Supremo Tribunal Federal.

Ensina CRETELLA JÚNIOR ${ }^{33}$ que foro privilegiado é aquele que cabe a al. guém, como direito seu, opondo-se ao foro comum, "precisamente porque é foro de juízo que não é o 'comum', ao passo que foro ou tribunal de exceção é o criado 'fora' ou 'dentro' da organização judiciária normal, ou comum, para o conhecimento e julgamento de um caso, ou de vários casos".

Com relação às justiças especializadas, ensina GRINOVER ${ }^{34}$ que o sistema constitucional brasileiro jamais mostrou aversão à instituição de justiças especializadas, mas pelo contrário, sempre francamente as admitiu. No seu entender, o sistema o fez com razão, na medida em que a garantia do juiz natural não se contrapõe a juízos especiais, orgânicos, préconstituídos, integrantes do Poder Judiciário, em que o que ocorre é apenas uma prévia distribuição de competências, ora em razão das pessoas, ora em razão da

33. CRETELLA JÚNIOR, José. Comentários à Constituição Brasileira de 1988. Rio de Janeiro: Forense Universitária, 1989, vol. (arts. 1 a 50, LXVIII), p. 464.

34. GRINOVER, Ada Pellegrini. O Princípio do Juiz Natural e a sua dupla garantia, O processo em sua unidade - II. Rio de Janeiro: Forense Universitária, 1984, p. 21 matéria. Para a autora "não se confundem, pois, tribunais de exceção - transitórios arbitrários - com justiça especializada - per manente e orgânica; os primeiros funcio nam ad hoc, para cada caso concreto, enquanto a segunda aplica a lei a todos os casos de determinada matéria ou que envolvam determinadas partes".

Exemplo de tribunal de exceção ocorrido em território nacional nos tra CRETELLA JÚNIOR, ${ }^{35}$ ao referir que em 1937, os três poderes encontravam-se nas mãos do ditador, que legislava, editando decretos-leis, que manejava a própria aplicação das leis no tribunal de exceção, e que administrava, aplicando a lei de ofício aos casos concretos. Se uma pessoa fosse acu sada de crime contra a existência, segurança ou integridade do Estado, contra a estrutura das instituições, contra a economia popular, contra a sua guarda ou o seu emprego, o tribunal de exceção é que teria competência para julgá-la.

De acordo com ALBUQUERQUE, ${ }^{36}$ não se deve alegar, também, inconsistência entre o princípio do juiz natural com o juizado penal militar, o qual está estruturado com bases já pré-definidas, e, portanto, em consonância com este princípio, pela mesma razão anteriormente aludida, qual seja a de que no sistema judiciário pode haver

35. CRETELLA JÚNIOR, José. Comentários à Constituição Brasileira de 1988. Rio de Janeiro. Forense Universitária, 1989, vol. I (arts. $1^{2}$ a $\left.5^{\circ}, L X V I I\right), p .465$

36. ALBUQUERQUE, Valéria Medeiros de. "Juiz Natural". In Revista Juridica Consulex, n’ 6, 1997, p. 35.

37. Cf. MARQUES, José Frederico. "Juiz Natural". In Enciclopédia Saraiva de Direito. vol. 46, p. 449

38. MARQUES, José Frederico. "Juiz Natural". In Enciclopédia Saraiva de Direito. vol. 46, p. 449

39. CF. MARQUES, José Frederico. "Juiz Natural". In Enciclopédia Saraiva de Direito. vol. 46, p. 446.

40. GRINOVER, Ada Pellegrini. O Princípio do Juiz Natural e a sua dupla garantia, O processo em sua unidade - II. Rio de Janeiro: Forense Universitária, 1984, p. 27. juízos ou varas especializadas, sem que isto viole ou atinja o princípio do juiz natural. que não se admite é a criação ad hoc de juízos especiais para o julgamento de determinada causa, embora dentro da própria ustiça ordinária. ${ }^{37}$ Contudo, "as atribuições que vem previsto na Constituição, nenhuma competência nova pode ser dada a essas justiças, porque então estaria sendo vado o princípio do juiz natural".38

Também não violam o princípio do juiz natural as chamadas modificações de competência, imediatamente aplicadas mas que já estejam contidas em leis regularmenenco ne direito ei previstas, os desaforamentos e a prorcompetência, desde que se realizem dentro do estritamente previsto em

Todavia, diversa apresenta-se a questão, no entender de GRINOVER, ${ }^{40}$ quanse trata de modificação de competência comum para a justiça especializaNesse caso deve ser estendida a atia do juiz natural à irretroatividade fação desta só pode ser feita para reger casos futuros. estabelecida por norma cons- 
Segundo a mesma autora, "outra violação ao princípio do juiz natural, instituída pelo legislador e ignorada pelos tribunais pátrios, é a que se configura pelo procedimento extrajudicial para execução de operações ligadas ao Sistema Financeiro de Habitação". ${ }^{41}$

O Decreto-lei $\mathrm{n}^{\mathbf{0}} \mathbf{7 0}$, de 21 de novembro de 1966 , e a Lei $\mathrm{n}^{\mathrm{o}} 5.741$ de $1^{\circ}$ de dezembro de 1971, ainda em vigor, estabelecem que tal execução se faça sob forma da ação executiva, em consonância com os arts. 31 a 38 do referido decreto, que fixam procedimento administrativo sumário, ins taurado mediante simples solicitação do credor ao agente fiduciário (antigamente Banco Nacional de Habitação, hoje extinto, substituído pela Caixa Econômica Federal), sem possibilidade de defesa, sem contraditório, sem fase de conhecimento, ainda que incidental e sem via recursal. Ocorre que, na maioria das vezes, o agente fiduciário também é o credor hipotecário. Nessa hipótese, concentram-se nas mãos da mesma entidade a legitimação ativa para a execução e a competência legal para os atos executórios, em flagrante violação da garantia do juiz natural. ${ }^{42}$

Uma questão ligada ao juiz natural, e que durante algum tempo suscitou polêmica, foi a do instituto da avocatória, in-

troduzido pela Emenda Constitucional no 7/1977, consistente no poder discricionário, atribuído ao STF, de avocar as causas processadas perante qualquer juízo ou tribunal em caso de "imediato perigo de grave lesão à ordem, saúde, à segurança ou às finanças públicas", com o objetivo de, suspensos os efeitos da decisão já proferida, o STF conhecer integralmente da lide.

Contudo, uma das argumentações contra a avocatória que aqui interessa - a supressão da garantia do juiz natural -, isto é, aquele órgão constitucionalmente designado para conhecer e decidir, em primeira mão, a causa que lhe é apresentada pelo jurisdicionado, não mais tem lugar nos dias de hoje. A Constituição brasileira de 1988, em seu art. 101, I, (competência originária), não fala mais em "avocação". O instituto não foi, pois, recepcionado pela nova ordem jurídica. ${ }^{43}$

CARVALHO ${ }^{44}$ traz um outro exemplo recente passível de infringência do princípio do juiz natural em sede do juizado da infância e da juventude. A questão referese à opção do chamado juiz imediato sem a observância da perpetuatio jurisdictionis e, por conseqüência, do juiz natural. Juízo imediato é entendido como aquele mais próximo do local onde se encontra o menor, no sentido de prestar-lhe uma prestação

41. GRINOVER, Ada Pellegrini. O Princípio do Juiz Natural e a sua dupla garantia, O processo em sua unidade - II. Rio de Janeiro: Forense Universitária, 1984, p. 24

42. Cf. GRINOVER, Ada Pellegrini. O Princípio do Juiz Natural e a sua dupla garantia, O processo em sua unidade - II. Rio de Janeiro: Forense Universitária, 1984, p. 25.

43. Cf. MACIEL, Adhemar Ferreira. "Avocatória: violação do juiz natural ou uma exigência de nossos tempos?" In Revista da Ordem dos Advogados do Brasil, 56, 1992, p. 124

44. CARVALHO, Jeferson Moreira de. "Juiz Constitucional, Juiz Imediato, Perpetuatio Jurisdictionis". In Revista da Escola Paulista da Magistratura, 1, 1996, p. 139.

jurisdicional mais rápida. Ocorre que às vezes há conflito entre o "juiz natural" e o juiz imediato.

Consta do acórdão 274 do conflito de competência 18.746.0/0 da Câmara Especial do Tribunal de Justiça de São Paulo que em sede de processo de menores não se aplica rigorosamente o princípio da perpectuatio jurisdictionis, no sentido de proporcionar uma justiça mais rápida. Como não se aplica rigorosamente o princípio da perpetuação, também não se aplica rigorosamente o princípio do juiz imediato, devendo-se verificar no caso concreto o que é mais benéfico ao menor.

$\mathrm{Na}$ área da Infância e da Juventude, então, conclui o autor, deve-se primeiro observar o princípio do juiz constitucional, e seqüencialmente a competência material, territorial e funcional. $O$ juiz imediato criado pelo ECA somente deve ser obedecido quando a criança ou adolescente estiver em situação legal de carência. ${ }^{45}$

Outra questão a ser analisada no que se refere ao alcance da garantia do juiz natural, é a constante do art. 5으, LIII que dispõe: "ninguém será processado nem sentenciado senão pela autoridade competente". Existiria, então, ao lado da garantia do juiz natural a garantia a um promotor natural, tendo-se em vista que, regra geral, em termos de ação penal, à exceção das ações penais privadas, é o Ministério Público o único titular da ação, e, portanto, o único legitimado a processar?

Para LOURES, ${ }^{46}$ o princípio do promotor natural assegura a preexistência de um órgão do Ministério Público, com atribuição estabelecida em lei, para o desenvolvimento da persecução penal em seus dois momentos: o da investigação e o da ação penal e dotado das garantias de inamovibilidade e independência funcional. Adiante adverte a autora que ainda que as intenções na nomeação de um promotor específico para determinado caso sejam as melhores, este mecanismo pode dar margem a grandes arbitrariedades, pondo em risco a melhor verificação dos fatos, através de redes de influência para que haja maior ou menor apuração da verdade. ${ }^{47}$

Ao comentar, à época, sobre o projeto de lei orgânica nacional do Ministério Público e o princípio do promotor natural, questiona CARNEIRO ${ }^{48}$ se seria possível o promotor renunciar a atribuição fixada em Lei Complementar à Constituição. Sua res. posta nada mais é do que a própria afirmação da necessidade da existência do promotor natural: "cremos que ela é irrenunciável, pelo simples fato de não ser um direito unicamente do Promotor e ainda que fosse seria certamente indisponível.

45. Cf. CARVALHO, Jeferson Moreira de. "Juiz Constitucional, Juiz Imediato, Perpetuatio Jurisdictionis". In Revista da Escola Paulista da Magistratura, 1, 1996, p. 142.

46. LOURES, Ana Beatriz. "Princípio do Promotor Natural. In Livro de Estudos Jurídicos. James Tubenchlak e Ricardo Bustamante (coord.). Rio de Janeiro: Forense, 1991, p. 239

47. LOURES, Ana Beatriz. "Princípio do Promotor Natural". In Livro de Estudos Juridicos. James Tubenchlak e Ricardo Bustamante (coord.). Rio de Janeiro: Forense, 1991, p. 241

48. CARNEIRO, Paulo Cezar Pinheiro. "O Princípio do Promotor Natural e o Projeto de Lei Orgânica Nacional do Ministério Público". In Livro de Estudos Jurídicos. James Tubenchlak e Ricardo Bustamante (coord.). Rio de Janeiro: Forense, 1991, p. 56. 
O princípio do Promotor Natural ao lado de consagrar o direito do membro do parquet de exercer as próprias atribuições - "ex vi legis" - constitui verdadeira garantia constitucional dos membros da sociedade, portanto, indisponível e irrenunciável".

De acordo com MAIA NETO, ${ }^{49}$ o princípio do Promotor Natural pode ser assim resumido: "Promotor Natural é todo aquele agente ministerial com poderes e atribuições administrativas e jurisdicionais exclusivas, previamente estabelecidas na Constituição, em lei penal adjetiva e nas normatizações ou instruções superiores do Ministério Público, devidamente publicadas nos órgãos da imprensa oficial da União ou dos Estados".

Adverte o mesmo autor que tanto os tribunais como as promotorias públicas de exceção instituídas para atender contingências particulares não se coadunam com o regime democrático. A competência do promotor natural, assim como a do juiz devem ser preestabelecidas.

Para PENTEADO, ${ }^{50}$ dado o campo de atuação do Ministério Público e o juízo axiológico que lhe defere a sociedade, é inevitável concluir-se que o princípio do promotor natural, isto é, que o fato de que os membros do parquet devem ter cargos específicos, proibidas as simples e discricionárias designações, afastando-se o promotor

de justiça ad hoc, está definitivamente inserido na Constituição da República.

Uma outra questão recente que tem causado polêmica em relação ao princípio do juiz natural é a que se revela a partir da vigência da Lei no 9.307/96, conhecida como lei de arbitragem. Pergunta-se: E o juízo arbitral Constitucional?

Segundo MENEZES e BORGES ${ }^{51}$ pode-se averiguar da inconstitucionalidade do instituto a partir dos seguintes argumentos: a) se há jurisdição feita pelo particular, portanto, um caso de justiça privada; b) se viola o princípio da efetividade; e c) se há violação do princípio do juiz natural (que aqui especialmente interessa para este estudo).

Segundo os autores, tem-se, pelo princípio do juiz natural, que todos os cidadãos possuem direito a um julgamento não apenas realizado por um juízo imparcial, mas, também, que a sua competência seja fixada pelas normas estabelecidas pela lei, no momento em que se dá o fato a ser dirimido, e, portanto, julgado. O juiz natural é, então, aquele previsto na Constituição, investido na função de julgar.

Por óbvio, então, em razão do princípio, não poderá haver juízos ou tribunais de exceção. Desde que criado post factum, não deixa de ser tribunal de exceção, mesmo que integrado exclusivamente por membros do Poder Judiciário. ${ }^{52}$

49. MAIA NETO, Cândido Furtado. "Promotor Natural e os Direitos Humanos". In Revista do Ministério Público. Porto Alegre: Nova Alvorada Ediçóes, 1997, n 39, p. 333 .

50. PENTEADO, Jaques de Camargo. "O Princípio do Promotor Natural". In RT619, 1987, pp. 410 e 411.

51. MENEZES, Cláudio Armando Couce de; e BORGES, Leonardo Dias. "Juízo Arbitral". In O Moderno Processo do Trabalho. São Paulo: LTr, 1997, p. 97.

52. Aqui os autores utilizam-se dos ensinamentos de José Carreira Alvim, em Elementos de Teoria Geral do Processo, p. 80.

Revista da Faculdade de Direito da UFRGS, v. 18, 2000
Portanto, segundo os mesmos autores, não há que se falar em inconstitu cionalidade em função da violação do princípio do juiz natural, visto que o juízo arbitral já encontra-se legalmente previsto em momento anterior ao que ocorre o fato a ser julgado, não existindo qualquer julga mento de exceção.

\section{Conclusão}

A tarefa de julgar, no dizer de ALBUQUERQUE, ${ }^{53}$ como um misto de trabalho científico e artístico, tem por objetivo transcender os conflitos humanos, devendo estar acima deles, criando direito, concedendo a uma das partes o poder coer citivo de impor à parte contrária o respeito ou atendimento a seu direito, e, com isto, contribuir para que se chegue à segurança jurídica, daí, efetivamente, decorrendo a paz social, o bem-estar, e a segurança de tida a coletividade.

Todos, portanto, devem ter o direito de ser julgados por um tribunal independente e imparcial, quer se trate de acusação penal, quer cuide de direitos ou obrigações da própria pessoa.

Quanto à origem histórica do princípio, conclui-se que a compreensão do mesmo na forma em que atualmente é concebido, é sucessiva à Magna Carta de 1215, derivando diretamente da Petition of Rights de 1627 e do Bill of Rights de 1688. Posteriormente, dada a sua importância para os cidadãos, o princípio acabou por encontrar abrigo em quase todos os textos constitucionais e internacionais modernos.
Especificamente no caso do Brasil, dentre todas as Constituições, somente a de 1967 e a Emenda de 1969 foram omissas a respeito. A Constituição Federal de 1988 não menciona a expressão "juiz natural" em um determinado artigo. Seu fundamento encontra-se disperso no texto da carta, de maneira mais ou menos explícita em mais de um dispositivo, entre eles o art. 5, XXXVII: "não haverá juízo ou tribunal de exceção"; o art. 5ํ, XXXV: "a lei não excluirá đa apreciação do Poder Judiciário lesão ou ameaça a direito"; o art. 5o, LIII: "ninguém será processado nem sentenciado senão pela autoridade competente"; o art. 5, XL: "a lei penal não retroagirá, salvo para beneficiar o réu".

O significado do princípio, para a maioria da doutrina, constitui-se em uma dúplice garantia: a proibição de juízo ou tribunal de exceção e julgamento por autoridade competente.

Quanto ao alcance do princípio, conclui-se que a vedação pela Constituição dos chamados Tribunais de Exceção, não se confunde com o foro privilegiado, previsto anteriormente ao fato e permitido por lei. Não existe ainda violação do princípio no que tange o juizado penal militar, visto que o mesmo está estruturado com bases prédefinidas, e previsto em lei.

Também não violam o princípio as modificações de competência imediatamente aplicadas mas já contidas em leis regularmente promulgadas.

53. ALBUQUERQUE, Valéria Medeiros de. "Juiz Natural". In Revista Jurídica Consulex, n 6, 1997, p 36. 
Dado o campo de atuação do Ministério Público, é inevitável concluir-se que o princípio do promotor natural, isto é, que seus membros devam ter cargos específicos, proibidas as simples e discricionárias designações, afastando-se a idéia do promotor ad hoc, está definitivamente inserido na Constituição da República.

Não há que se falar, de outra parte, em inconstitucionalidade em função da violação do princípio do juiz natural face ao juízo arbitral, visto que o mesmo já encontra-se legalmente previsto em momento anterior ao que ocorre o fato a ser julgado, não existindo, portanto, julgamento de exceção.

Qualquer pessoa deve ser julgada por um juiz, previamente designado para aquele cargo determinado sem qualquer outra consideração. Com isto, a confiança na neutralidade do juiz daquele que procura a justiça é reforçada. Além disso, com relação ao princípio da igualdade, leva-se em conta que, com fundamento nas mesmas exigências, qualquer pessoa terá direito ao mesmo juiz.

\section{Bibliografia}

ALBUQUERQUE, Valéria Medeiros de. "Juiz Natural". In Revista Jurídica Consulex, no 6, 1997, pp. 35-36.

BASTOS, Celso Ribeiro e MARTINS, Ives Gandra. Comentários à Constituição do Brasil. São Paulo: Saraiva, 1989, $2^{\circ}$ vol. (arts. 5 a 17).

CARNEIRO, Paulo Cezar Pinheiro. "O Princípio do Promotor Natural e o Projeto de Lei Orgânica Nacional do Ministério Público". In Livro de Estudos Jurídicos. James
Tubenchlak e Ricardo Bustamante (coord.) Rio de Janeiro: Forense, 1991, pp. 55/60.

CAPELLETTI, Mauro. Fundamental Guarantees of the parties in Civil Proceeding (General Report).

CARVALHO, Jeferson Moreira de. "Juiz Cons titucional, Juiz Imediato, Perpetuatio Jurisdictionis". In Revista da Escola Paulista da Magistratura, no 1, 1996, pp. 139/142.

COUTURE, Eduardo J. "La Garanzia Costituzionale del 'Dovuto Processo Legale". In Rivista di Diritto Processuale, no 2, 1954 pp. 81/101.

CRETELLA JÚNIOR, José. Comentários à Cons tituição Brasileira de 1988. Rio de Janeiro: Forense Universitária, 1989, vol. I (arts. 10 a 5o, LXVII), pp. 462/528.

FERRAJOLI, Luigi. Derecho y Razón (Teoria del Garantismo Penal). Madrid: Trotta, 1995, pp. 589/591.

GOMES, Luiz Flávio. "Apontamentos sobre o Princípio do Juiz Natural". In RT 703, 1994 pp. 417/422.

GRINOVER, Ada Pellegrini. O Princípio do Juiz Natural e a sua dupla garantia, O processo em sua unidade - II. Rio de Janeiro: Forense Universitária, 1984, pp. 3/40.

LARENZ, Karl. Derecho Justo. Fundamentos de Etica Juridica. Trad. de Luis Díez-Picazo. Madrid: Civitas, 1985.

LIEBMAN, Enrico Tullio. "Giudice naturale e costituzione del giudice". (Sentenze e note). In Rivista di Diritto Processuale, 1964, pp. 331/ 337.

LOURES, Ana Beatriz. "Princípio do Promotor Natural". In Livro de Estudos Jurídicos. James Tubenchlak e Ricardo Bustamante (coord.) Rio de Janeiro: Forense, 1991, pp. 238/249.

MACIEL, Adhemar Ferreira. "Avocatória: vio lação do juiz natural ou uma exigência de nossos tempos?" In Revista da Ordem dos Advogados do Brasil, no 56, 1992, pp. 117/ 125.

MAIA NETO, Cândido Furtado. "Promotor Natural e os Direitos Humanos". In Revista do Ministério Público. Porto Alegre: Nova Alvorada Edições, 1997, nº 39, pp. 331/335.

MARQUES, José Frederico. "Juiz Natural". In Enciclopédia Saraiva de Direito. vol. 46, pp. 444/450.

MENEZES, Cláudio Armando Couce de; e BORGES, Leonardo Dias. "Juízo Arbitral".
In O Moderno Processo do Trabalho. São Paulo: LTr, 1997, pp. 85/132.

PENTEADO, Jaques de Camargo. "O Princípio do Promotor Natural". In RT 619, 1987, pp. 407/413.

SCHWAB, Karl Heinz. "Divisão de Funções e o Juiz Natural". Trad. de Nelson Nery Júnior. In Revista de Processo, no 48, 1987, pp. 124/ 131.

TUCCI, Rogério Lauria. "Juiz Natural e Competência em Tribunal." In RT 765, 1999, pp. $7 / 107$. 